\title{
National Internationalization Processes SME on the Way to Eastern Europe
}

\author{
Meyer, Klaus E.; Tind, Ane; Jacobsen, Mår K.
}

Document Version

Final published version

Publication date:

2000

\section{License \\ CC BY-NC-ND}

Citation for published version (APA):

Meyer, K. E., Tind, A., \& Jacobsen, M. K. (2000). National Internationalization Processes: SME on the Way to Eastern Europe. CEES, Copenhagen Business School. Working Paper / Center for East European Studies. Copenhagen Business School No. 37

Link to publication in CBS Research Portal

\section{General rights}

Copyright and moral rights for the publications made accessible in the public portal are retained by the authors and/or other copyright owners and it is a condition of accessing publications that users recognise and abide by the legal requirements associated with these rights.

Take down policy

If you believe that this document breaches copyright please contact us (research.lib@cbs.dk) providing details, and we will remove access to the work immediately and investigate your claim. 


\section{CEES}

Working Paper No. 37

June 2000

National Internationalization Processes:

SME on the way to Eastern Europe

by

Klaus Meyer

Ane Tind,

Mår K. Jacobsen

Center for East European Studies

Copenhagen Business School 



\title{
National Internationalization Processes: \\ SME on the way to Eastern Europe
}

\author{
Klaus E. Meyer \\ Center for East European Studies, Copenhagen Business School, Frederiksberg, Denmark \\ with \\ Ane Tind \\ Post Denmark, Copenhagen, Denmark \\ and \\ Mår K. Jacobsen \\ Nilfisk Advance A/S, Brøndby, Denmark
}

CEES Working Paper no. 37

June 2000

\section{Keywords:}

Internationalization Process, Business Networks, Market Entry, Austria, Denmark, Russia

Contact: Klaus Meyer, Associate Professor

Center for East European Studies, Copenhagen Business School

Dalgas Have 15, DK-2000 Frederiksberg F, Denmark

Tel.: +45 3815 3033, Fax +45 3815 3037, e-mail: km.cees@cbs.dk,

http:॥www.econ.cbs.dklinstituteslcees/stafflmeyer.html

Acknowledgements: the authors thank all questionnaire respondents and interview partners for their contribution. We are moreover grateful to Peter Krag, Christina Pind and participants of seminars at the Vienna Institute for International Economics (WIIW) and at the Copenhagen Business School as well as AIB conference participants in Charlston, SC, USA and IBR reviewers for their helpful comments on this research. 


\section{National Internationalization Processes:}

SME on the way to Eastern Europe

Going alone on an adventure tour can be hazardous. Good friends help, if only through their advice. The same holds true for small businesses aiming for major international markets. They rely on information, support services and networks that are jointly built up with business partners. Business communities therefore follow a joint path of gradual internationalization that resembles the internationalization of firms described by Uppsala scholars.

We present a model that integrates business networks with the internationalization process model to explain international business of small and medium size enterprises (SME). While global multinationals may be able to tap into several clusters and networks, SMEs are to a large extent part of the internationalization process of their national economy.

Our survey evidence points to differences in the home country environment that explain why Danish firms, relative to Austrian firms, are less active. Our case evidence sheds more light on the dynamics of entry, as events in the network, and expansion of the network, motivate increased commitment.

\section{Introduction}

Going alone on an adventure tour can be hazardous. Good friends help, if only through their advice. Before climbing Mt Everest aspiring mountain climbers, gamblers apart, would prepare themselves in many ways: by studying reports on previous expeditions, by obtaining the most suitable equipment possibly custom-made, by extensive training, and by organizing support by a group of local Sherpas to escort them for most of the way. Every successful adventurer benefits from support by many people, some of whom he/she may have met by chance in a local pub.

The same holds for small and medium size enterprises (SME) aiming at international markets. They extensively draw upon information, experiences and support services shared with partners in their home environment. This network provides a knowledge-pool that grows with the experiences of the partners while providing stimuli, sometimes apparently at random, to pursue business opportunities. Decisions about internationalization are influenced directly and indirectly by the home environment and by 
corporate networks. Business communities therefore follow a joint path of gradual internationalization that resembles the internationalization of firms described by Johanson and Vahlne [1990] and others.

We therefore integrate network analysis [Johanson and Mattson 1998, Easton and Axelsson 1992] into the internationalization model. International entry requires not only knowledge of international business as such, but country-specific expertise. This is particularly relevant for partner countries with a very different economic, political and cultural environment, such as East European transition economies - the focus of this paper. Business networks facilitate exchange of such knowledge; and the dynamics of the network thus in turn influence firms internationalization behaviour. We thus follow empirical researchers of SME, who suggest to combine models of the internationalization process with network models [e.g. Bjorkman and Kock 1997, Coviello and Munro 1997, Fontes and Coombs 1997].

The next section thus introduces a model of internationalization processes at a national level as the theoretical foundation of the study. We then present empirical findings of two complementary studies on the static and dynamic elements of the model. The survey in section four reports managers' perception of Russia-specific expertise in their firms and their home environment in Denmark and Austria. Section five summarizes cases of small Danish businesses, pointing to the role of networks, and of chance, in internationalization. Section six discusses the results in a broader context, and section seven points to further research.

\section{Internationalization Processes}

SME are embedded and, more than large multinationals, typified by their domestic business environment. Their technological and managerial capabilities are developed under the influence of national culture, institutions and common knowledge. Furthermore, their 'ownership advantages' [Dunning 1993] include internal assets and capabilities, as well as resources created in collaboration with firms in their domestic and international business networks, or shared in the wider business environment, and embodied in its institutions, culture or shared knowledge, i.e. 'what is known to most persons in a group or society'. Firms' competitiveness is thus interdependent with that of their national business community, sub-national business clusters [Porter 1990] or industrial districts [Kristensen 1989]. 
Figure 1: Internationalization Processes

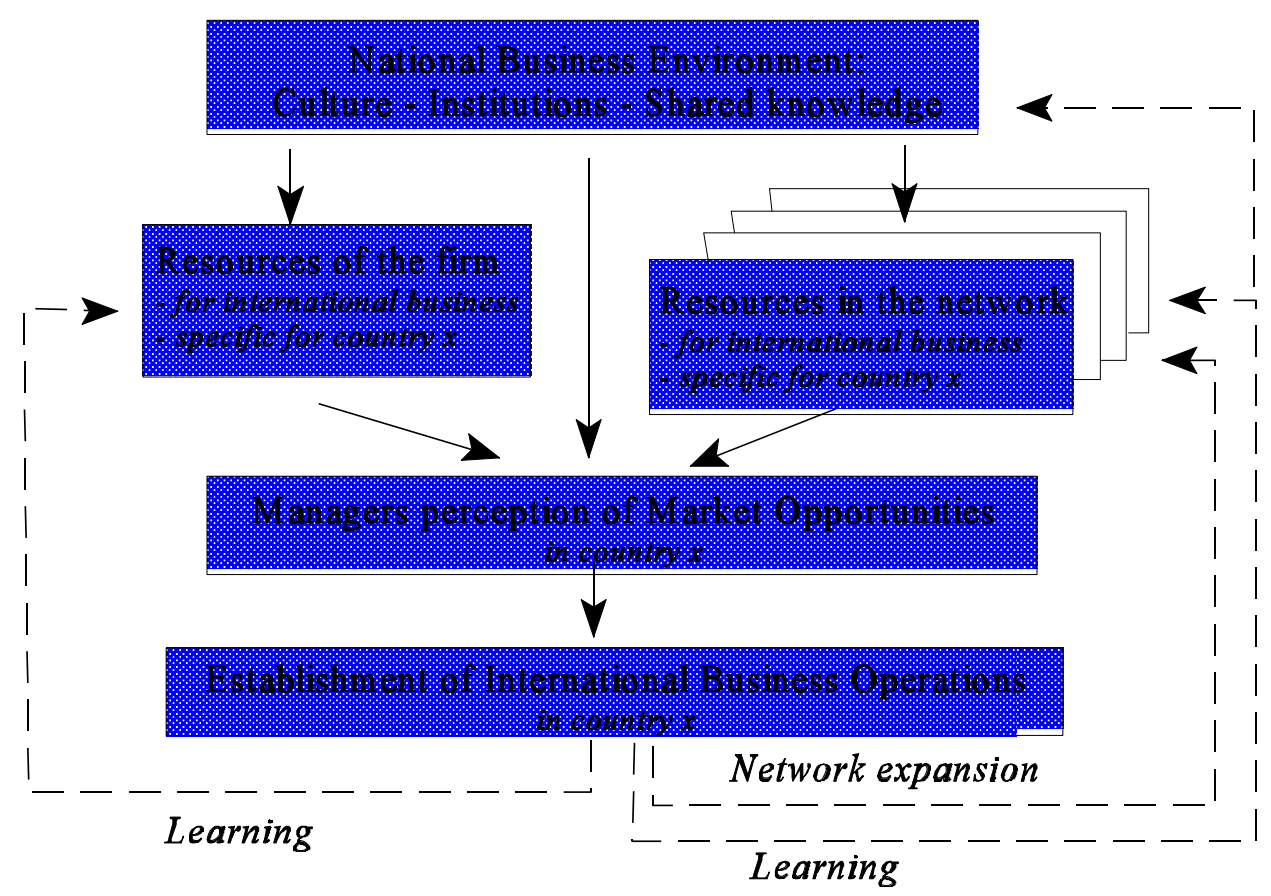

The internationalization of SME is co-evolving with the internationalization of their national business environment. Institutions establish international contacts through membership in supra-national organizations (e.g. WTO, ILO) or bilateral co-operation (e.g. chambers of commerce). Shared knowledge on other countries' culture, business and languages grows through media coverage, education, and personal contacts. Even culture evolves in response to international interactions, e.g. increasing awareness and tolerance of cultural diversity. In combination, these factors constitute national competitive advantages, which are a foundation of firms' competitive advantages, and determine the country's outward international business (Figure 1).

Many of the resources crucial for international business are knowledge-based. They include both knowledge on how to do international business, and expertise specific to the chosen foreign country, such as knowledge on local markets, business practices and institutional conditions. This 'country-specific knowledge' (in this paper this term always refers to knowledge on the foreign partner country) may reside in the firm itself, in its national business environment, or in its business networks at home and abroad.

Availability of such knowledge is crucial for an entry process into a specific region. It provides a competitive advantage that improves the investment decision and all subsequent strategic and operational decisions. Lack of information is a particular serious obstacle for small firms [e.g. Seringhaus 1987] because information is an indivisible 
resource, and small firms cannot spread its costs across a large volume of exports in the way that a large firm can. The information sought includes formal knowledge, i.e. hard facts, that can be obtained via blueprints or consultancy reports. However, more important for international entry is experiential knowledge [e.g. Reid 1984], including expertise in leadership, cross-cultural management and local business cultures.

Formal knowledge is easier to acquire, provided one knows it exists and who has it. Obtaining data on, say, consumer behaviour in a remote market, thus requires prior knowledge about sources. Experiential knowledge, such as the understanding of a foreign business culture, can be transferred through active involvement, preferably in the host country itself, but not in codified form. This knowledge forms part of the capabilities of the organization, or its individual members. Therefore, entry starts with the collection of information and the transfer of experiences from different business contexts. Accumulating experiential knowledge, most firms then follow a path of gradual deepening of their commitment in foreign markets. This internationalization process [Johanson and Vahlne 1977, 1990] occurs for each entry into a new market.

Country-specific expertise is arguably of particular importance in transition economies. Entrants need to build specific expertise to overcome administrative and cultural barriers that arise with the specific business culture formed during the region's history, and amended by the socialist experience of the 20th century [e.g. Michailova 2000]. Moreover, the incomplete institutional framework poses special challenges for inexperienced newcomers [e.g. Meyer 2000].

Hence, the interaction of the home country business environment with the chosen partner country contributes to the evolution of institutions, culture, and country-specific knowledge. This in turn influences outward international business, as we propose in our first proposition:

Proposition 1: Partner country-specific capabilities that are embedded in firms' home environment facilitate their internationalization into that partner country.

The country-specific knowledge evolves, both within the firm [Johanson and Vahlne 1990] and within its environment. Knowledge is accumulated by interaction with the environment and with business partners in particular. Thus, business networks, that is long-term business relationships between at lest two partners [e.g. Thorelli 1986], 
facilitate the internationalization process. ${ }^{1}$ Networks reinforce the internal learning process, they interact with corporate strategies, and they add an element of chance to business opportunities.

We define business networks as long-standing relationships between legally independent firms, that exploit mutual complementarities and exchange information. They are neither coordinated through an organizational hierarchy nor through the market, but through interaction among actors in the network, generally based on mutual trust and/or common long-term interests [Johanson and Mattson 1988]. Some networks are tightly structured, with high interdependence and strong bonds. However, we also consider loosely structured networks where bonds are weak and considerable 'networking', i.e. exchange of valuable information', occurs informally.

Actors in a network are engaged in combination, development, exchange and creation of new products and services by use of their individual resources [Håkanson 1987]. This joint activity includes the exchange of experiential knowledge, which is feasible on the basis of shared knowledge and the principles of coordination of the network itself. Knowledge on business in a foreign country can therefore, partially, be shared within a business networks [e.g. Holmlund and Kock 1998] leading to a co-evolution of the learning process in the firm and its network. This interaction not only enhances individual capabilities of the firms, but leads to capabilities not controlled by one firm, but inherent in their interaction [Kogut 2000].

Second, business networks have a crucial role in SME strategies. They not only determine firms' strategic opportunities, but also become an object of strategic activity. Network positions determine the firm's strategic position and the resources it can access. Yet, network positions themselves are generally a result of earlier investments in the network. Actors continuously improve relations to existing network partners that have been useful to the organization, while creating new networks in search of new business opportunities [Håkanson 1987]. In this perspective, internationalization is the process of firms aiming (i) to develop existing positions and increase resource commitments in profitable nets, (ii) to increase the coordination between positions in different national nets, and (iii) to establish positions in new networks [Johanson and Mattson 1988]. The internationalization of a firm is thus an evolutionary process of a developing business

\footnotetext{
${ }^{1}$ Several studies explore the role of networks for SME establishing international business, see Coviello and McAuley [1999] for a review. Andersen and Christensen [1999] illustrate it for a Danish case.
} 
network with a changing role of the firm within its network. Relationships are developed as bridges into foreign markets [Sharma and Johanson 1987]. Decisions over entry, or increased commitment to a market, thus require orientation over the current structure of the network and repositioning of the firm within the network [Axelsson and Johanson 1992].

Third, the influence of networks on internationalization adds to strategic planning an element of serendipity, i.e. fortunate and unexpected discoveries made by chance. Resources held in a firm's network may be gained or lost as partners enter or leave the network. For instance, new acquaintances offer un-anticipated opportunities by providing complementary resources, knowledge, or contacts. The network evolves outside the control of the firm as resources in the network cannot be managed to the same extent as internal resources. In particular, knowledge within the firm is concentrated and readily accessible with at least some degree of control over the learning process. Knowledge possessed by the network partners is dispersed, harder to recognize and to combine, and its accumulation is generally beyond the control of the firm.

Johanson and Vahlne's internationalization model suggests a gradual and continuous deepening of international commitments. Similarly, networks evolve evolutionary, which implies gradual change, yet with possible radical change in reaction to extraordinary situations. Disturbances in the wider business environment can trigger revolutionary changes in the focal firm's corporate strategy such as foreign entry. The influence of events in the network on firms' entry decisions thus adds a chaotic element to internationalization processes, providing a less deterministic perspective on entry behaviour. The flexibility to adjust and the ability to react to emerging opportunities are therefore key capabilities for international business development.

Several authors point to the special importance of network relations for business within Eastern Europe [e.g. Stark 1996, Puffer et al. 2000, Todeva 2000] and for international business relationships with transition economies [Bridgewater 1999, Salmi 1999]. We thus posit that business networks are crucial for the dynamics of entry processes in the region:

Proposition 2: Firms' internationalization co-evolves with the internationalization of their networks, as they can draw upon resources created in the network and react to opportunities arising with business partners. 
Figure 1 sums up the theoretical arguments. The national business environment contributes to firms' ownership advantages, which are located in the firms and their networks. Managers perception of market opportunities and obstacles is influenced by the (internal) resources of the firm and the resources of its network, as well as by its national environment. Resources in both the firm and the network are continuously enhanced by learning processes, yet with qualitative differences. In addition, the network itself expands as a result of the international activity, and through exogenous events.

\section{Methodology}

Following a "multimethod design" [Brewer and Hunter 1989], we undertook two empirical studies that employ survey and case data respectively. While each method has its unique strength, using multiple lenses not only enhances external validity, but allows us to explore both the static and dynamic aspects of our model. In section four, we present survey data on Russia-specific capabilities in the national business environments in Denmark and Austria. In section five, we explore the dynamics of the process through case research in 20 small Danish firms.

\section{Study One: Comparative Survey}

\subsection{National Business Environments}

The survey study has been designed to assess the business environment in two small open European economies with comparable economic structures, Denmark and Austria, with respect to East European markets, especially Russia. Russia has emerged as a major partner for international business in the 1990's. Despite the financial crises of 1998, she can be expected to become a key market for West European businesses. Danish and Austrian business involvement in Russia varies considerably; with Denmark apparently lagging behind, as Danish foreign direct investment (FDI) reached only a cumulative total of US\$ 33 million in 1997 [Meyer and Pind 1999]. The apparently weak Danish position has been the starting point for our investigation, and we chose Austria as a benchmark country.

Austria and Denmark are not only of similar size in terms of population and of GDP (Denmark US\$ 176.3 billion, Austria US\$217.2 billion in 1998) but they also have similar business structures. The economies are dominated by small and medium size businesses; inward foreign investors have an important role; and manufacturing contributes a major 
share to GDP. These economic similarities contrast however with a different historical evolution of relationships with the East European economies, and Russia in particular.

Danish business with Russia was very extensive until World War I. In 1914, Russia was the third most important export market for Denmark [Jacobsen 1997]. With the revolution, almost all Danish businesses in the Soviet Union were expropriated. During the cold war, Denmark has been exporting to the Soviet Union on a small scale through the state trading agencies, accounting for substantially less than $1 \%$ of Danish trade from 1918 to 1988. In contrast, the Soviet-Union entered the Austrian economy as an occupying force in 1945 [e.g. Bellak 1998]. After regaining full sovereignty, Austria retained special business contacts with Russia, in addition to its historical relationships with its neighbours. A major share of East-West trade during the cold war was administered through neutral Austria. Although Austrians may not cherish the memory, history provided Austria with contacts and skills that became valuable for business in the 1990s.

Both Danish and Austrian businesses expanded eastwards after the fall of the Iron Curtain. Austria reestablished business links with Hungary and other neighbouring countries and was at an early stage in 1990 the largest investor in the region [Neudorfer 1997, Altzinger and Winklhofer 1998, Meyer 1998]. Many SMEs were quick to realize new opportunities while Austrian affiliates of MNEs invested on behalf of their parent firms. Austrian businesses invested more than US\$ 500 million annually (Table 1).

Danish investment in CEE reached US\$ 250 million in 1996. Businesses focussed on countries around the Baltic sea, notably Poland and the Baltic states. Poland ranks seventh among locations for Danish affiliates abroad [Dansk Industri 1998]. Both Austrian and Danish firms entered Russia in a second stage of their eastward expansion; and they committed far less investment capital - a wise precaution in view of the recent macroeconomic turmoil.

\section{Table 1: Outward Foreign Direct Investment}

in million US\$

\begin{tabular}{|c|c|c|c|c|c|c|c|c|c|c|}
\hline & \multicolumn{5}{|c|}{ Denmark } & \multicolumn{5}{|c|}{ Austria } \\
\hline & 1994 & 1995 & 1996 & 1997 & 1998 & 1994 & 1995 & 1996 & 1997 & 1998 \\
\hline Total FDI & 3961 & 3070 & 2518 & 4210 & 4333 & 1200 & 1130 & 1934 & 1987 & 2818 \\
\hline FDI in CEE, in \% & 1.6 & 7.6 & 11 & 6.5 & 2.3 & 57.6 & 47.3 & 26 & 48.5 & 37.3 \\
\hline FDI in Russia, in \% & 0 & 0.1 & 0.2 & 0.4 & 0.8 & 0.6 & 0.2 & 0.6 & 3.3 & 1.9 \\
\hline
\end{tabular}

Note: CEE = Central and Eastern Europe, including the CIS countries.

Sources: OECD (1999), correspondence with Danish National Bank, own conversion in US\$. 


\subsection{The Enterprise Survey}

We surveyed Danish and Austrian businesses to develop a deeper understanding of Russia specific capabilities in the firms' home environment [Jacobsen and Meyer 1999]. We contacted all firms known to be active in Russia, and for whom we could identify the necessary contact information. In this, we went beyond other studies in that we consider not only companies with FDI but all that have any kind of international business activity.

The questionnaire was translated into the local language and sent to key informants in the firms. ${ }^{2}$ Fifty Danish and 144 Austrian firms were contacted in May 1998, returning 62 completed questionnaires (32\%). The return rate was $50 \%$ for Danish firms and $26 \%$ for Austrian firms. ${ }^{3}$ The difference reflects international experiences with cross-cultural questionnaire surveys,${ }^{4}$ and may have been helped by more precise contact information for Danish firms.

The firms in the survey sample are engaged in a variety of business activities. The most common operations are import/export (47\%), services (39\%), and establishment of sales offices $(40 \%)$ or representative offices (37\%). Austrian firms appear to prefer the former, whereas Danish firms prefer the latter type of office, which may reflect the earlier stage of their entry process. Eleven firms (19\%) have established production in Russia, and only five firms (9\%), mostly Austrian, source raw materials in the region.

\subsection{Country-specific Resources}

The first proposition suggests that national business environments differ to the extent that they provide resources for business with specific partner countries, which in turn influence the

\footnotetext{
2 The questionnaire was first designed in English, then translated into German and Danish by independent translators and verified by means of back-translation. As both authors understand all three languages, we are confident that the translations are precise. The questionnaire was sent along with a cover letter containing a confidentiality statement, and a pre-paid return envelop. Respondents were thanked with a copy of the results if they had included a business card with their response.

${ }^{3}$ The Danish firms are those whose details were provided by the Danish embassy in Moscow. The Austrian firms are taken from a list by the Wirtschaftforschungsinstitut Österreich of 686 firms active in Russia, and for whom contact details could be identified in the Austrian company guide published on CD by Austrian Telecom. Contact persons in the Danish companies have been identified in 'Kraks virksomhedsdatabase on CD' as responsible either for the former Soviet Union or for international investment. In some cases, the CEO was contacted.

${ }^{4}$ Return rates differ internationally due to, among other things, cultural differences. On a systematic crosscultural study on return rates, Harzing [1998] found the return rate for Danish firms to be $42.1 \%$, the highest of all countries. Austrian firms completed only $19.0 \%$ of the questionnaires. Being aware of the different return pattern, we sent the Austrian sample firms a reminder fax, which led to additional returns. Altzinger and Winkelhofer [1998] obtained a return of $16.8 \%$ for a similar study in Austria. By these comparisons our return rates are more than satisfactory.
} 
firm's outward business activity. To establish which resources are most important, we first report respondents own assessment of the importance of various country-specific qualifications when taking decisions to establish operations in Russia. Table 2 shows the results in two ways, the average rank assigned to each aspect, and the frequency with which respondents included an aspect in their ranking. The results indicate that the most important qualification is actual experience. Having 'worked with Russia and Russians for more than three years' has been mentioned by twenty respondents who assigned it on average rank 1.8. Such experience is thus considered more important than formal knowledge, lending support to the emphasis on experiential knowledge in the theoretical argument.

Table 2: Perceived Importance of Management Qualifications

\begin{tabular}{|c|c|c|c|c|c|c|}
\hline & \multicolumn{3}{|c|}{ Average Rank } & \multicolumn{3}{|c|}{ Number of Mentions } \\
\hline & Danish & Austrian & Total & Danish & Austrian & Total \\
\hline $\begin{array}{l}\text { They have been working with Russia and } \\
\text { Russians for more than } 3 \text { years }\end{array}$ & 1.8 & 1.8 & 1.8 & 11 & 9 & 20 \\
\hline They speak Russian & 2.7 & 2 & 2.4 & 7 & 7 & 14 \\
\hline They have lived in Russia for one year or more & 2.7 & 2.4 & 2.6 & 7 & 5 & 12 \\
\hline $\begin{array}{l}\text { They are having private visitors from Russia } \\
\text { regularly }\end{array}$ & 2.9 & 3 & 2.9 & 7 & 4 & 11 \\
\hline They have close personal friends from Russia & 3.3 & 3.6 & 3.5 & 6 & 5 & 11 \\
\hline They are Russian expatriates & 2 & 3.9 & 3.7 & 1 & 9 & 10 \\
\hline $\begin{array}{l}\text { They have taken university courses which focus } \\
\text { on doing business with Russia }\end{array}$ & 4.2 & 5.5 & 4.8 & 5 & 4 & 9 \\
\hline They have relatives from Russia & 4.3 & 5 & 4.8 & 3 & 5 & 8 \\
\hline $\begin{array}{l}\text { They know the Russian partner from their } \\
\text { university studies }\end{array}$ & 2.6 & 3.5 & 2.9 & 5 & 2 & 7 \\
\hline
\end{tabular}

Note: Respondents were asked to rank the importance that these qualifications had for the companies decision to invest in Russia. For each qualification, the table reports the average rank (most important $=$ rank 1$)$ and the number of respondents that included it in their ranking.

The second most important qualification, by rank and by number of mentions, is the command of the Russian language. Languages have an important role in multinational companies, but are often underrated by the leadership [Marschan et al. 1998]. They facilitate the communication between individuals in different business units. While the leadership in headquarters and affiliates may adopt a common language, in Nordic companies frequently English, this language is often not used by middle management and shop floor employees. In extreme cases this has led to an inability of expatriate managers to communicate directly with 


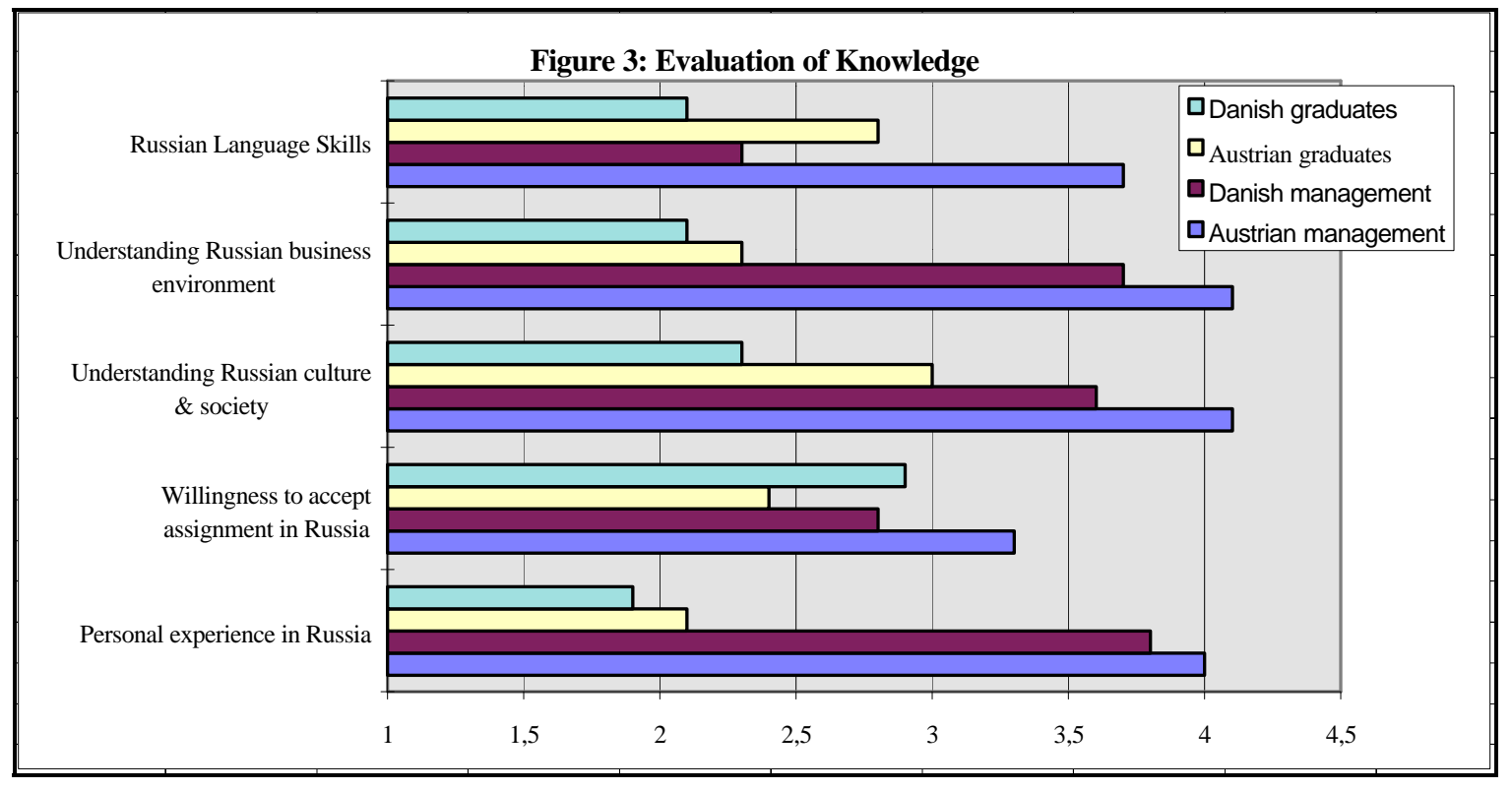

local employees in Russia, and can become a serious obstacle to organizational performance [Michailova 2000]. ${ }^{5}$

Next to experience in Russia and language skills, further personal and professional experiences are ranked. They give managers direct contacts with the country, or people from there, and thus permit some experiential learning. 'Russian expatriates' are frequently mentioned by Austrian respondents, but only by one Danish respondent. University courses are mentioned by several respondents, but they rank low as they provide formal education and little experiential knowledge. On the other hand, contacts dating from university are mentioned only by seven respondents, but ranked relatively high by them. Joint education creates common experiences and personal relationships and thus networks. The 'coincidence' of an existing personal acquaintance, or friendship, can at some stage become a business asset.

The actual human resources available in the firms and their environment matches in part the profile of qualifications perceived to be important, yet with some differences between the countries. We asked about the human resources in the firms directly, while those in the business environment are proxied by respondents assessment of university graduates, the most important source for future recruitment.

Austrian managers receive high marks for their capability to act on Russia markets (Figure 3). At least those firms active in Russia appear to have access to qualified employees. Danish

\footnotetext{
${ }^{5}$ In study two, we observed that key people in Danish firms normally do not speak East European languages, but in addition to English (and Danish), they often command one other language good enough to establish business contacts - typically German or French. Often, one key person in the CEE firm has good language skills, and becomes the key contact. Yet, when this person is not available, then serious communication problems occur.
} 
firms can draw upon less Russia-specific expertise, especially with respect to language skills. University graduates are naturally rated lower, especially with regard to aspects that encompass experiential knowledge, which can primarily be obtained on the job. Yet, also among graduates, the Austrians outperform their Danish colleagues except for the "willingness to accept assignment in Russia'. These differences are grounded in different national business environments, especially the education system and historical relations with Eastern Europe as outlined above.

The differences are largest in the case of language skills. Respondents report that far more people in Austria speak Russian, both among managers and among university graduates. Many Austrian respondents rated Russian language skills as good or extremely good: 59\% said this about managers and $27 \%$ about graduates. Only $18 \%$ of the Danish managers and $6 \%$ of the Danish graduates received this evaluation. ${ }^{6}$

The survey of knowledge-based resources thus suggests that (a) practical experience and language skills are considered the most important forms of country-specific expertise, and (b) Danish managers and graduates are not as well prepared as their Austrian counterparts when engaging in business in Russia, especially with regards to language skills.

In addition to managerial resources, the national business environment provides key sources of information. To overcome information barriers to international business, firms use a wide variety of sources [e.g. Burke and Casson 1998]. In our sample, almost all respondents indicated personal contacts as a source, and three out of four used business connections (Table 4). Personal and professional networks are essential because key practical knowledge is held by those actually engaged in business. Institutions such as chambers of commerce and embassies can collect and disseminate such information, if at all, only in stylized, form. Moreover, the close interaction with network partners allows some transfer of experiential knowledge [Makino and Delios 1996]. The institutions that provide information vary between the two countries, reflecting different roles of supporting organizations in different national business systems.

\footnotetext{
${ }^{6}$ One reason for good Russian skills in the present generation of 60-year olds in Austria is that during the occupation period 1945-1955, students in the Russian zone had to study Russian language in high school.
} 
Table 4: Sources of Information

in $\%$ of respondents

\begin{tabular}{lccc}
\hline & Austria & Denmark & Total \\
\hline Personal connections & $89 \%$ & $91 \%$ & $89 \%$ \\
Business connections & $80 \%$ & $73 \%$ & $77 \%$ \\
Chamber of commerce & $46 \%$ & $5 \%$ & $30 \%$ \\
Ministry of foreign affairs & $14 \%$ & $36 \%$ & $23 \%$ \\
Commercial banks & $23 \%$ & $23 \%$ & $22 \%$ \\
National Bank & $11 \%$ & none & $7 \%$ \\
Other government agency & $3 \%$ & none & $2 \%$ \\
Other & $6 \%$ & $14 \%$ & $9 \%$ \\
\hline
\end{tabular}

Note: Number of observations: 54 , percentages do not add to $100 \%$ as respondents could mark multiple options.

Table 5: Main sources of financing Russian operations

in $\%$ of respondents

\begin{tabular}{lccc}
\hline & Austrian & Danish & Total \\
\hline Internal resources & $88 \%$ & $95 \%$ & $91 \%$ \\
Bank loan & $36 \%$ & $20 \%$ & $30 \%$ \\
Private loan & $9 \%$ & $5 \%$ & $8 \%$ \\
EBRD & $6 \%$ & $5 \%$ & $6 \%$ \\
Governmental program & $6 \%$ & $15 \%$ & $9 \%$ \\
Other source & $12 \%$ & $10 \%$ & $11 \%$ \\
\hline
\end{tabular}

Note: Number of observations: 51 , percentages do not add to $100 \%$ as respondents could mark multiple options.

One fifth of the respondents also used their bank to obtain information. Beyond this, many SMEs use their main bank for funding business abroad, making banks a crucial element in national business environments. However, the most important source of finance are internal resources, which reflects the high risk of such business (Table 5). Bank loans are used by two fifths of Austrian firms but only one fifth of the Danes. Austrian banks have expanded very rapidly eastwards in the 1990s and may thus be better placed to support businesses with the region. Asked for a recommendation as banking partner, Danish respondents often mentioned an international bank (e.g. from Germany), while Austrians were more inclined to name a bank from their own country. Danish firms are relying more on governmental programs, such as the Investment Fund for Central and Eastern Europe (IØ-fonden).

In conclusion, we observe differences in the national business environments between Denmark and Austria with respect to both specific managerial resources and supporting institutions. The higher level of Russia-specific expertise in Austria correlates with her larger 
business involvement, which supports proposition 1 . The data moreover point to the importance of experiential knowledge and business connections. These we explore in more detail in the second study that focuses on the dynamics of networks.

\section{Study Two: The Dynamics of Business Networks}

We explored the dynamics of networks in the internationalization process through a series of 20 cases of small Danish manufacturing and trading firms with up to 25 employees. Denmark is an interesting place to study business networks as they play an important role in the competitiveness of SME in Danish industrial districts [e.g. Andersen and Kristensen 1999]. The cases are based on one-hour-long interviews with the general manager or the export manager resulting in 7 to 12 pages of interview transcripts each. They covered activities in CEE, in addition to Russia, focussing on the entry decision and development. In the following, the 20 cases are referred to as firms $a, b, \ldots t$.

Most of the case firms export to CEE (90\%), some in combination with a representative office $(15 \%)$, a sales-JV (10\%) or a sales subsidiary (15\%). All but one firm established business contacts after 1987, and they had on average five years of experience in the region at the time of the interviews in 1998. The sales volumes are in most cases small, with $60 \%$ of firms exporting less than $5 \%$ of their turnover to the region. However, firms $s$ and $t$ are specialized trading firms exporting all their exports to the region. Firms $a$ and $d$ are procuring from the region, respectively from their JV or a subcontracting partner.

The cases provided us with new insights on the dynamics of networks. Business networks have an essential role in their internationalization processes as they provide complementary resources especially information, reinforce learning processes and create coincidences that may lead to identification of new business opportunities. Interviewees mentioned among their partners domestic firms with business activity in Eastern Europe as well as firms based in third countries and, especially post-entry, firms in the region itself. Thus, in a small open economy, even small businesses rely not only on national networks. In fact, few distinguished explicitly between national and international business relationships.

We expected networks to have an pivotal role in establishing business. Yet we were surprised how many interviewees indicated some coincidence triggering the interest in establishing business. A prior contact with future partners was the most important determinant when choosing a market within the region, for instance via trade fair contacts: 
Q.: "How have you established contact with your partners in Eastern Europe?"

A.: "It is coincidental. Either I meet some through co-partners from other markets or through meeting people from our trade fairs where we exhibit. There is a big trade fair in Frankfurt. ... when someone approaches us and seems serious enough, we do business, but we do not investigate opportunities in Eastern Europe pro-actively" (Firm i, manufacturer of household goods in plastic).

"Next to our booth was a booth from Lithuania ... They had some products which were totally unsalable, but they were extremely interested in our wares... One of them was a woman, who had just established a company in Riga and was extremely eager and promised that she wanted to buy a lot from us, and she claimed she had money to do so. After the fair, I went to Riga where she had provided an interpreter so we could communicate. Then she began to order goods" (Firm m, trading in leather).

Table 6 categorizes the firms and their East European entries according to what triggered the entry. Incidences like those reported in the citations are no exceptions: Only half the case firms engaged in systematic search activities before engaging in business in a country of the region. On the other hand, 15 of the 20 firms engaged in business following up an opportunity arising by chance, for instance via a contact established at a trade fair, or being contacted directly by the future business partner. Of these firms, five entered a new country following up upon an event in their network. Thus, in addition to initiatives by existing partners, entry of new partners into the network is a typical event triggering international entry.

Active search ${ }^{7}$ appears more common in large and - as predicted by the internationalization model - nearby countries, while 'chance' appears more important in peripheral (other) markets, in this study Hungary, Czech Republic and Yugoslavia. Yet, the mode of establishing contact does not appear to influence the future volume of business. Active search has been reported more frequently for first entries than for subsequent entries, while initiative from local businesses motivated subsequent entries of Danish firms already established in a country of the region.

${ }^{7}$ Firms included under 'Active' had an pro-active approach to establishing business in CEE. The actual selection of a partner-firm, or even the partner-country was still subject to chance - for instance firm d's manager's Estonian girl-friend appears to have influenced his decision indirectly. On the other hand, firms in the 'active search' category frequently report problems in finding the right partner (more than, they say, in other regions where they do business). Some report failed business contacts as partners were not capable to deliver agreed services, or pay. 
Table 6: Search versus Chance motivating foreign expansion

Statement that most closely matches the case

\begin{tabular}{|c|c|c|c|c|c|c|c|c|c|}
\hline & \multicolumn{5}{|c|}{ Country } & \multicolumn{2}{|c|}{ Entry } & \multicolumn{2}{|c|}{ Industry $^{d}$} \\
\hline & $\#^{\mathrm{a}}$ & Poland & Russia & Baltics & other & $1^{\mathrm{st}}$ & $2^{\text {nd }} / 3^{\text {rd }}$ & M & $\mathrm{T}$ \\
\hline \multirow{2}{*}{$\begin{array}{l}\text { "We actively searched for } \\
\text { business opportunities" b }\end{array}$} & 10 & 5 & 7 & 4 & 2 & 10 & 7 & 5 & 5 \\
\hline & & $\begin{array}{l}\mathrm{j}, \mathrm{s}, \mathrm{k}, \\
\mathrm{p}, \mathrm{r}\end{array}$ & $\begin{array}{l}\mathrm{c}, \mathrm{j}, \mathrm{k} \\
\mathrm{o}, \mathrm{p}, \mathrm{s}, \mathrm{t}\end{array}$ & $\mathrm{d}, \mathrm{j}, \mathrm{s}, \mathrm{h}$ & $\mathrm{h}, \mathrm{k}$ & $\begin{array}{l}\mathrm{c}, \mathrm{d}, \mathrm{j}, \mathrm{o} \\
\mathrm{p}, \mathrm{r}, \mathrm{s}, \mathrm{h} \\
\quad \mathrm{k}, \mathrm{t}\end{array}$ & $\begin{array}{l}\mathrm{s}, \mathrm{h}, \mathrm{j} \\
\mathrm{k}, \mathrm{p}\end{array}$ & $\begin{array}{l}\mathrm{c}, \mathrm{d}, \mathrm{h}, \\
\mathrm{j}, \mathrm{k}\end{array}$ & $\begin{array}{l}\mathrm{o}, \mathrm{p}, \\
\mathrm{r}, \mathrm{s}, \mathrm{t}\end{array}$ \\
\hline $\begin{array}{l}\text { "Contact with future partner } \\
\text { occurred by chance and led to } \\
\text { business with that country" }\end{array}$ & 15 & 5 & 5 & 5 & 7 & 10 & 11 & 10 & 5 \\
\hline $\begin{array}{l}- \text { trade fairs } \\
----------\end{array}$ & 9 & $\mathrm{n}, \mathrm{k}$ & $\mathrm{i}, \mathrm{g}, \mathrm{o}$ & $\begin{array}{l}\mathrm{e}, \mathrm{i}, \mathrm{m} \\
-\underline{\mathrm{q}}-\end{array}$ & $\begin{array}{l}\mathrm{c}, \mathrm{e}, \mathrm{i} \\
\mathrm{k}\end{array}$ & $\begin{array}{l}\mathrm{e}, \mathrm{g}, \mathrm{m} \\
\mathrm{n}, \mathrm{q}\end{array}$ & $\begin{array}{l}\mathrm{c}, \mathrm{e}, \mathrm{i} \\
\mathrm{k}, \mathrm{m}, \mathrm{o}\end{array}$ & $\begin{array}{l}\mathrm{c}, \mathrm{e}, \mathrm{g} \\
\mathrm{i}, \mathrm{k}, \mathrm{q}\end{array}$ & $\begin{array}{l}\mathrm{m}, \mathrm{n}, \\
- \\
-\end{array}$ \\
\hline $\begin{array}{l}\text { - initiative by future partner } \\
-----------\end{array}$ & 6 & --- & $\mathrm{i}, \mathrm{n}, \mathrm{r}$ & $\begin{array}{r}\mathrm{i} \\
-\mathrm{C}\end{array}$ & $\begin{array}{c}\mathrm{b}, \mathrm{f}, \mathrm{i} \\
\mathrm{m}, \mathrm{q}\end{array}$ & -- & $\begin{array}{l}\mathrm{b}, \mathrm{f}, \mathrm{i} \\
\mathrm{n}, \mathrm{q}, \mathrm{r}\end{array}$ & $\begin{array}{l}\mathrm{b}, \mathrm{f}, \mathrm{i}, \mathrm{q} \\
---\end{array}$ & $\mathrm{n}, \mathrm{r}$ \\
\hline - network ${ }^{\mathrm{c}}$ & 5 & $a, b, f$ & $\mathrm{i}$ & $\mathrm{i}, 1$ & $\mathrm{i}$, & $\mathrm{a}, \mathrm{b}, \mathrm{f}, \mathrm{i}, \mathrm{l}$ & $\mathrm{i}$ & $\mathrm{a}, \mathrm{b}, \mathrm{f}, \mathrm{i}$ & 1 \\
\hline Total \# firms ${ }^{\text {a }}$ & 20 & 9 & 12 & 9 & 8 & 20 & 16 & 12 & 8 \\
\hline
\end{tabular}

Notes:

${ }^{\mathrm{a}}$ : Entries are listed by firm. Row and column total refer to the number of firms in the row/column, excluding double counts that arise from multiple entries (e.g. firms j, k) and multiple motives (especially firm i).

b : "Active search" includes travel in the region, local representatives, consultants, specific recruitment, pre-1990 contacts, contacts established via the Danish embassy in the country etc.

${ }^{c}$ : Networks generating chance incidences include initiatives or recommendations by unrelated business contacts or intermediaries, and in one ace an ex-employees originating in CEE.

${ }^{\mathrm{d}}: \mathrm{M}=$ manufacturing, $\mathrm{T}=$ trading firms.

The businesses interviewed emphasised relations with local business partners. Personal connections are widely used, and are often intertwined with professional ones. The importance of personal relationships with Eastern partners was emphasized by the following managers:

"The Russians are weary of strangers. Just as we believe they cheat, they also suspect us of cheating. There have been many scams in Russia, so they know they have to be careful. In this connection, the most essential is to create trust. Personal relationships are important ... We do business with the person not with his company" (Firm j, manufacturing electronics).

"It is of great importance for the East European that you are a friend. You cannot visit a customer without taking time to have a meal with him. You know their wives etc." (Firm r, trading in foods). 
“... with East Europeans, you are either friend or not friend. We are friends and cannot even sleep in a hotel. They want to invite us to their homes and see their family" (Firm

a, manufacturing plastic pallets in Poland).

These statements suggest that personal relationships are more important in transition economies than in Scandinavia, which is in line with other studies [e.g. Salmi and Bäckman 1999]. The importance of trust and the reliance on personal relationships and networks has its origins both in the Russian culture [Holden et al. 1998, Vlachoutsicos 1998] and, relatedly, in the lack of legal institutions that would ensure contract enforcement [e.g. Thornton and Mikheeva 1996].

Overall, the experience of the 20 Danish case firms suggests that networks play an pivotal role in managing and expanding business in CEE, even if they may be less crucial as motivator for entry. We interpret the empirical evidence as support for proposition 2, although further research is required to establish the feedback-loops. However, we find confirmed that the development of an international business network is an important dimension of the internationalization process.

\section{Discussion}

Together, the results illustrate internationalization processes that evolve interdependently with firms, business networks, and supporting institutions. Stepwise commitments to a foreign market correspond with the agents' learning about the local environment. They accumulate knowledge interactively within their business networks, exchanging knowledge with partners in their industrial or regional cluster. Especially SMEs draw upon the expertise in the local economy and its supporting institutions when considering a commitment to a foreign market. This leads to a gradual deepening of the international business by an industry from a given country [also see Luostarinen 1978].

The internationalization process model in this form can explain the entry of Danish and Austrian businesses in Russia. Firms take their decisions over entry based on knowledge and contacts that they, or their partners, have. The country-specific knowledge is often experiential and therefore hard to communicate between unrelated partners. Other knowledge, such as corporate strategies, may be highly confidential or difficult to verify and can therefore only be obtained if a high level of trust connects the partners [Burke and Casson 1998]. Trust is however higher within small communities, and for instance higher between two Danes than between a Dane and a local consultant. The existing knowledge-base within a network therefore influences the commitments of its members to the foreign market, which in turn promotes further learning. 
This leads to a cumulative process of knowledge acquisition and deepening of the business. Since it is experiential knowledge that is essential in this process, it can cross the boundaries of organizations, and of (national) industrial clusters only to a limited extent. The process is reinforced by the evolution of business networks as events within networks can trigger major strategic decisions. One partner may enter a foreign market, and draw its partners along as local turnover grows. Or, a new acquaintance joins the network creating unforseen opportunities. While global multinationals may be able to tap into several clusters and networks, SMEs are to a large extent part of the internationalization process of their national economy.

For managers, this implies that sensitivity and flexibility to react to events in the network and to new business contacts are crucial capabilities for successful internationalization. Establishing and maintaining networks is an important business activity, especially in Eastern Europe and other emerging markets. Moreover, investment into national networks, education infrastructure and other supporting institutions, may augment the resource base shared by the firms in the economy. Thus co-operation at home may strengthen outward international business.

\section{Direction for further research}

This research proposed a new framework to integrate business networks into the analysis of internationalization processes. We focused on the entry to a specific foreign country, emphasizing the partner-country-specific aspects of both knowledge accumulation and network development. The empirical evidence, based on both a survey and in-depth interviews, illustrates the relevance of variables identified in the theoretical model.

Further research should test propositions arising from the model in a more formal setting, based on a larger sample. Specific issues to be considered include differentiation of types of network relationships, relevance of the model businesses of different size and international experience, and variation across home and host economies. For instance, is the importance of network relations specific to transition economies? This should moreover integrate aspects such as type of operations and sales volumes into the analysis. On this basis, factors influencing the performance operations abroad should be reassessed and tested. Furthermore, longitudinal studies of entry, under consideration of the evolution of networks and the home business environment, should provide valuable insights. 


\section{References}

Altzinger, W. and R. Winklhofer (1998): General patterns of Austrian FDI in Central and Eastern Europe and a case study, Journal of International Relations and Development 1, p. 65-83.

Andersen, P.H. and P.R. Christensen (1999): Internationalization in loosely coupled business systems: The Danish case, in: P. Karnøe, P. H. Kristensen and P. H. Andersen, eds.: Mobilizing Resources and Generating Competences: The Remarkable Success of Small and Medium-sized Enterprises in the Danish Business System, Copenhagen: Copenhagen Business School Press, p. .205231.

Andersen, P.H. and P.H. Kristensen (1999): The systemic qualities of Danish industrialism, in: P. Karnøe, P. H. Kristensen and P. H. Andersen, eds.: Mobilizing resources and generating competences: The remarkable success of small and medium-sized enterprises in the Danish business system, Copenhagen: Copenhagen Business School Press, p. .299-331.

Axelsson, B. and J. Johanson (1992): Foreign market entry - The textbook vs. the network view, in B. Axelsson and G. Easton, eds.: Industrial networks: A new view of reality, London: Routledge, p. 218-234.

Bellak, C. (1997): Austrian manufacturing MNEs: Long-term perspectives, Business History 39, no. 1, p. 47-71.

Bjorkman, I. and S. Kock (1997): Inward international activities in service firms Illustrated by three firms from tourism industry, International Journal of Tourism Industries Management 8, p. 362-376.

Brewer, J. and A. Hunter (1989): Multimethod research: A synthesis of styles. Newbury Park, CA: Sage.

Bridgewater, S. (1999): Networks and internationalisation: The case of multinational corporations entering Ukraine, International Business Review 8, p. 99-118.

Burke, S. and M. Casson (1998): Information strategies in foreign market entry: Investing in sales and distribution activities, Academy of International Business Conference, Vienna, October 1998.

Coviello, N.E. and A. McAuley (1999): Internationalzation of the smaller firm: A review of contemporary empirical research,
Management International Review 39, p. 223-256.

Coviello, N.E. and H.J. Munro (1997): Network relationships and the internationalisation of small software firms, International Business Review 6, p. 1-26.

Dansk Industi (1998): Danske virksomheders etableringer $i$ udlandet: Hovedresultater af etableringsundersøgelsen 1998. København: Dansk Industri.

Dunning, J.H. (1993): Multinational enterprises and the global economy, Addison-Wesley.

Fontes, M. and R. Coombs (1997): The coincidence of technology and market objectives in the internationalisation of new technology-based firms, International Small Business Journal 15, p. 14-35.

Harzing, A.-W. (1998): Response rates in international mail surveys: Results of a 22country study, International Business Review 6, p. 641-665.

Holden, N., C. Cooper and J. Carr (1998): Dealing with the new Russia: Management cultures in collision, Chichester et al.: Wiley.

Holmlund, M. and S. Kock (1998): Relationships and the internationalisation of Finnish small and medium sized companies, International Small Business Journal 16, p. 46-63.

Håkanson, H. (1989): Industrial technical development - A network approach, London: Routledge.

Jacobsen, K. (1997): The Great Northern Telegraph Company: A Danish company in the service of globalisation since 1969, in: S. Tønnesson, J. Koponen, N. Steensgaards and T. Svensson, eds.: Between national histories and global history, Helsinki: FHS.

Jacobsen, M.K. and K.E. Meyer (1998): Opportunities in Russia: Internationalization of Danish and Austrian businesses, Working Paper no. 17, Center for East European Studies, Copenhagen Business School, December.

Johanson, J. and L.G. Mattson (1988): Internationalization in industrial systems - A network approach, International Studies of Management and Organization 17, p. 34-48.

Johanson, J. and J.-E. Vahlne (1977): The internationalization process of the firm, A model of Knowledge development and increasing foreign market commitment, Journal of International Business Studies, Spring/Summer. 
Johanson, J. and J.-E. Vahlne (1990): The mechanism of internationalisation, International Marketing Review 7, no. 4, p. 11-24.

Karnøe, Peter, Peer Hull Kristensen and Poul Houman Andersen, eds. (1999): Mobilizing resources and generating competences: The remarkable success of small and mediumsized enterprises in the Danish business system, Copenhagen: Copenhagen Business School Press.

Kogut, B. (2000): The Network as knowledge, Strategic Management Journal 21, p. 405425.

Kristensen, P.H. (1989): Denmark: an experimental laboratory for new industrial models, Entrepreneurship and Regional Development 1, p. 245-255.

Luostarinen, R. (1979): Internationalization of the firm: An empirical study of the internationalization of firms with small and open domestic markets with special emphasis on lateral rigidity as a behavioural characteristic in strategic decision making. Helsinki: Helsinki School of Economics, 3rd ed. 1989.

Makino, S. and A. Delios (1996): Local knowledge transfer and performance: implications Alliance Formation in Asia, Journal of International Business Studies 27, p. 904-928.

Marschan, R., D. Welch and L.Welch (1997): Language: The Forgotten Factor in Multinational Management, European Management Journal 15, p. 591-598.

Meyer, K.E. (1998): Direct Investment in Economies in Transition, Aldershot: Elgar.

Meyer, K.E. (2000): Transition Economies, in: T. Brewer and A. Rugman, eds.: Oxford Handbook of International Business, Oxford: OUP, forthcoming.

Meyer, K.E. and C. Pind (1999): The Slow Growth of Foreign Direct Investment in the Successor States of the Former Soviet Union, Economics of Transition 7, p. 201-214.

Michailova, S.(2000): John, we are Not in the West Any Longer: Expatriates and Planning Change in a Russian Context, Academy of Management Executive, forthcoming, November.

Neudorfer, P. (1997): The Opening of Central and Eastern Europe: The Case of Austrian Foreign Direct Investment, Focus on
Transition (Austrian National Bank), 2/1997, p. 52-68.

Porter, M.E. (1990): The Competitive Advantage of Nations: London: MacMillan.

Puffer, S.M., D.J. McCarthy and A.I. Naumov (2000): The Russian capitalist experiment, Cheltenham: Elgar.

Reid, S. (1984): Information acquisition and export entry decisions in small firms, Journal of Business Research 12, p. 141-157.

Salmi, A. (1996): Russian Networks in Transition: Implications for Managers, Industrial Marketing Management 25, p. 3745.

Salmi, A. (1999): Entry into Turbulent Business Networks: The Case of a Western Company on the Estonian Market, European Journal of Marketing 34.

Salmi, A. and J. Bäckman (1999): Personal relations in Russian business: Two circles, in: R. Kosonen and A. Salmi, eds.: Institutions and post-socialist transitions; Helsinki: Helsingin Kauppakorkeakoulun Julkaisuja, p. 139-168.

Seringhaus, F.H.R. (1987): The role of information assistance in small firm export involvement, International Small Business Journal 5 (2), p. 26-36.

Sharma, D. and J. Johanson (1987): Technical consultancy in internationalisation, International Marketing Review, Winter, p. 20-29.

Stark, D. (1996): recombinant property in East European capitalism, American Journal of Sociology 101, p. 993-1027.

Thorelli, H.B. (1986): Networks: between markets and hierarchies, Strategic Management Journal 7, p. 37-51.

Thornton, J. and N.N. Mikheeva 1996: The strategies of foreign and foreign-assisted firms in the Russian Far East: Alternatives to missing infrastructure, Comparative Economic Studies 38, no. 4, p. 85-120.

Todeva, E. (2000): Comparative business network in Eastern Europe, Journal of EastWest Business, forthcoming.

UNCTAD (1998): World investment report 1998: Trends and determinants, UN: Geneva.

Vlachotsicos, C. (1998): Russian communitarianism: An invisible fist in the transformation process in Russia. Working paper no. 120, William Davidson Institute, University of Michigan Business School, January. 